\title{
INFLAMMATORY ODONTOGENIC CYST IN A CHILD: CASE REPORT
}

\author{
Çocuk Hastada Inflamatuar Odontojenik Kist: Olgu Sunumu
}

\section{Kamile Nur TOZAR ${ }^{1^{*}(D)}$, Merve ERKMEN ALMAZ ${ }^{2}$, Hatice ÖNDER ${ }^{3}$ (D) Fethi ATIL $^{4}$ (D), Emre BARIŞ5}

\author{
${ }^{1}$ Adlyaman University Faculty of Dentistry, Department of Pediatric Dentistry, ADIYAMAN, TÜRKIYYE \\ ${ }^{2}$ Kirlkkale University Faculty of Dentistry, Department of Pediatric Dentistry, KIRIKKALE, TÜRKIYE \\ ${ }^{3}$ Kirlkkale University Faculty of Dentistry, Department of Oral and Maxillofacial Surgery, KIRIKKALE, TÜRKIYE \\ ${ }^{4}$ Mersin University Faculty of Dentistry, Department of Oral and Maxillofacial Surgery, MERSIN, TÜRKIYE \\ ${ }^{5}$ Gazi University Faculty of Dentistry, Department of Oral Pathology, ANKARA, TÜRKIYE
}

\section{ABSTRACT}

Odontogenic cysts arise from epithelium residuals forming the tooth. When they are infected, they can reach large sizes and cause bone resorption in the surrounding bone.

A 9-year-old girl who was brought to Department of Pediatric Dentistry was referred to the Department of Oral and Maxillofacial Surgery due to a suspicion of a cystic lesion in the premolar region of the patient's right lower jaw as a result of clinical and radiographic examinations. Fine needle aspiration biopsy was performed after the patient's cone beam computed tomography was taken, and the specimen was sent to pathology. Histopathologically, cyst with suppurative inflammation was diagnosed. Then, the treatment was planned and marsupialization method was chosen considering the size of the lesion, the age of the patient, and the presence of impacted tooth in the region concerned.

As a result of a 14-month follow-up, the radiography of the patient showed that although the cyst was not enucleated, radiolucency in the related region disappeared and the tooth number 45 erupted to the oral cavity. In this way, it was considered that marsupialization treatment was a successful method.
Odontojenik kistler dişi oluşturan epitel artıklarından meydana gelmektedir. Enfekte olduğu durumlarda büyük boyutlara ulaşabilmektedir ve çevredeki kemik dokuda rezorbsiyona neden olabilmektedir.

Kliniğimize başvuran 9 yaşındaki kız hastaya yapılan klinik ve radyografik tetkikler sonucu, hastanın sağ mandibular premolar bölgesinde kistik bir lezyondan şüphelenilerek hasta Ağız, Diş ve Çene Cerrahisi bölümüne sevk edilmiştir. Hastadan konik 1şınlı bilgisayarlı tomografi alınmış ve lezyondan ince iğne aspirasyon biyopsisi yapılarak sonuç patolojiye gönderilmiştir. Histopatolojik olarak; süpüratif inflamasyon içeren kist tanısı konmuştur. Yapılan tedavi planlamasında, lezyonun büyüklüğü, hastanın yaşı ve ilgili bölgede gömülü diş varlığ göz önünde bulundurularak marsüpyalizasyon yöntemi tercih edilmiştir.

14 aylık takip sonucunda hastadan alınan radyografide kistin enükle edilmemesine rağmen ilgili bölgedeki radyolüsensinin kaybolduğu ve 45 nolu dişin ağız ortamına sürdüğü gözlenmiştir. $\mathrm{Bu}$ doğrultuda marsüpyalizasyon tedavisinin başarılı bir yöntem olduğu düşünülmektedir.
Keywords: Cyst, marsupialization, mandibula, pediatric patient
Anahtar Kelimeler: Kist, marsüpyalizasyon, mandibula, çocuk hasta 


\section{INTRODUCTION}

The cyst is a pocket surrounded by pathological epithelium and filled with fluid or semi-liquid material, which is usually drawn into the cavity by hydrostatic pressure (1). As the maxilla and mandible contain abundant epithelial remains, they are the bones in which cysts are most commonly seen (1). Cysts formed by dental tissues are called odontogenic cysts $(1,2)$. Odontogenic cysts are classified into two groups as developmental and inflammatory. Radicular cysts are in the inflammatory group, and dentigerous and odontogenic keratocysts are in the developmental cyst group. The most common radicular cyst among the odontogenic cysts originates from the root of the devital tooth, while the second most common dentigerous cyst is seen around the impacted tooth (26).

Odontogenic cysts can reach large sizes when infected and may cause resorption in the surrounding bone. In the present case, an inflammatory odontogenic cyst was treated in a 9-year-old child, and the permanent premolar tooth in the cyst boundary erupted into the oral cavity.

\section{CASE REPORT}

A 9-year-old girl who was admitted to the Department of Pedodontics, Faculty of Dentistry was suspected of having a cystic lesion in the right mandibular premolar region and was referred to the Department of Oral and Maxillofacial Surgery (Figure 1).

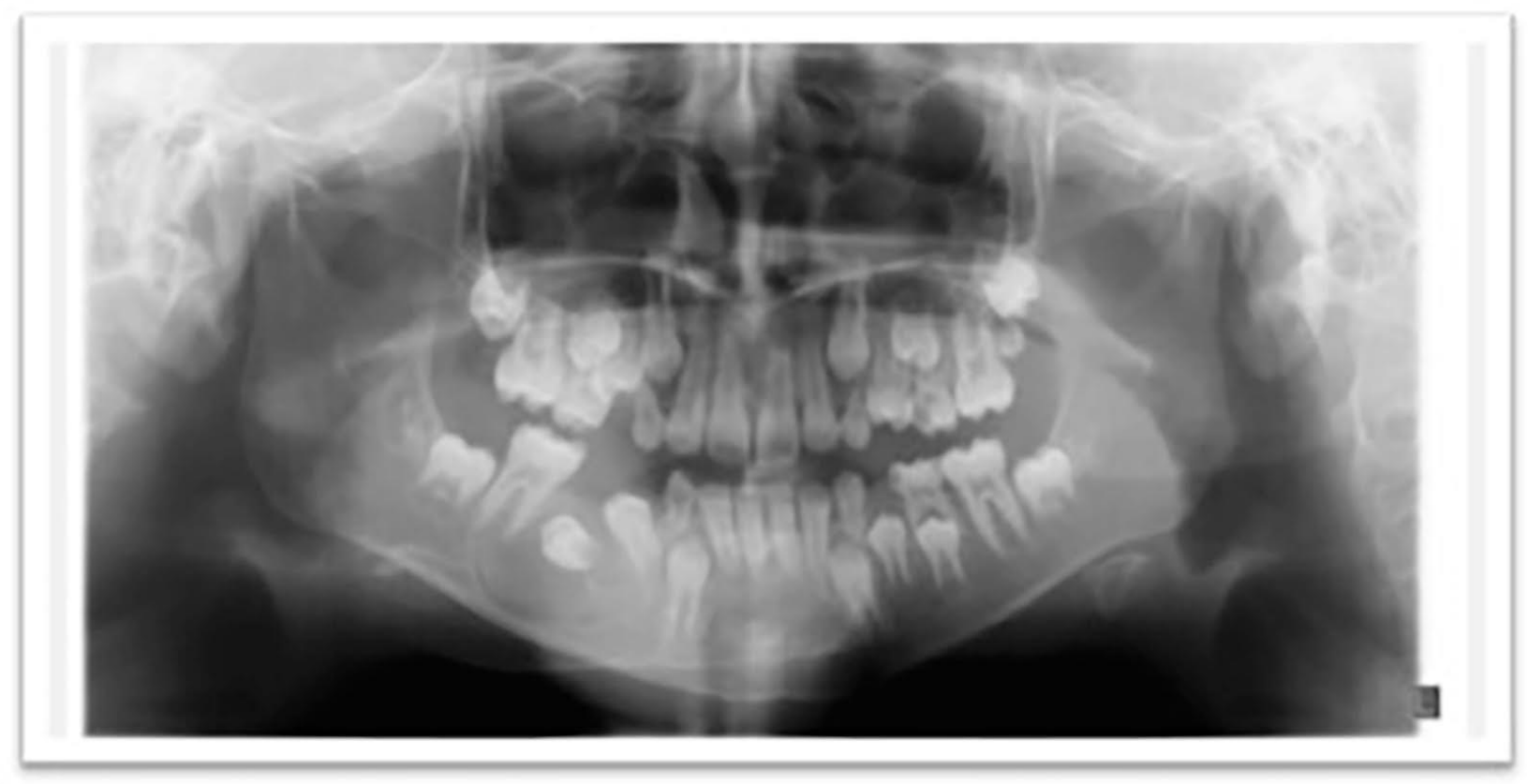

Figure 1: Pre-treatment panoramic radiography of the patient.

No lymphadenopathy was detected in the patient's lymph nodes examination. Cone beam computed tomography was taken and fine needle aspiration biopsy was performed, and the specimen was sent to pathology. In the pathology report, the sample showed dense inflammatory cells consisting entirely of neutrophils on fibrin and erythrocyte background. Histopathologically, the cyst was diagnosed as suppurative inflammatory. In treatment planning, marsupialization treatment was preferred considering the size of the lesion, the age of the patient, and the presence of an impacted tooth in the region. Written 
informed consent was obtained from the patient and the parents.

In this treatment, the cyst epithelium was joined to the oral mucosal epithelium by opening a window over the crest top and the pressure in the cavity was reduced by placing an appropriate sized drain. In this way, the cyst was expected to shrink. The patient washed the cavity
3-4 times a day for 3 months. At the end of month 3, the drain was removed.

As a result of a 14-month follow-up, the radiography of the patient showed that although the cyst was not enucleated, radiolucency in the related region had disappeared and the tooth number 45 erupted to the oral cavity (Figure 2, 3).

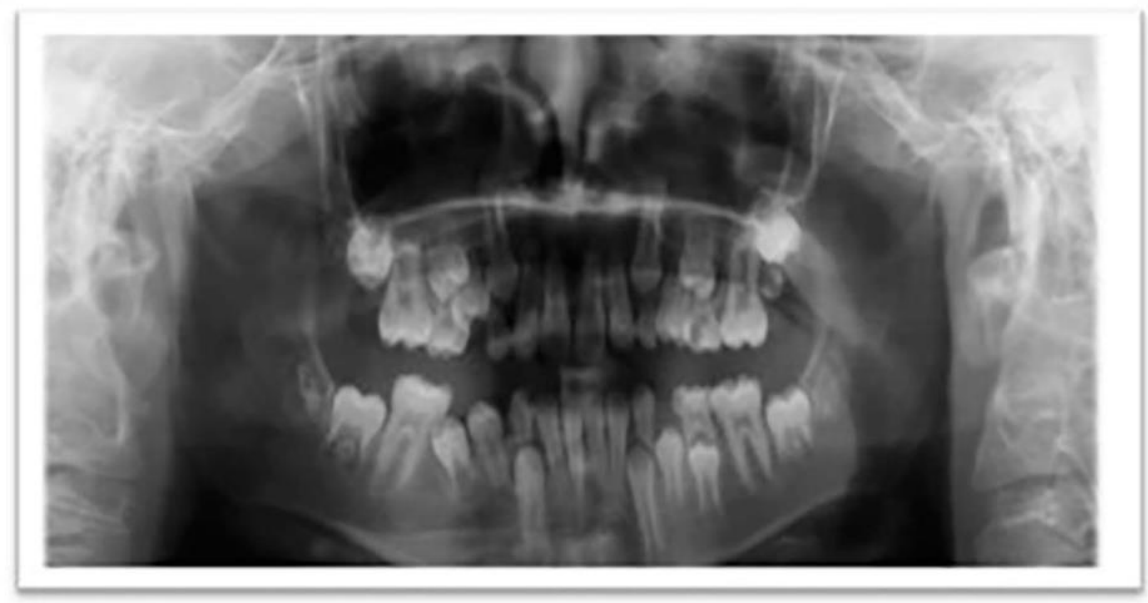

Figure 2: Post-treatment panoramic radiography of the patient (month 14).

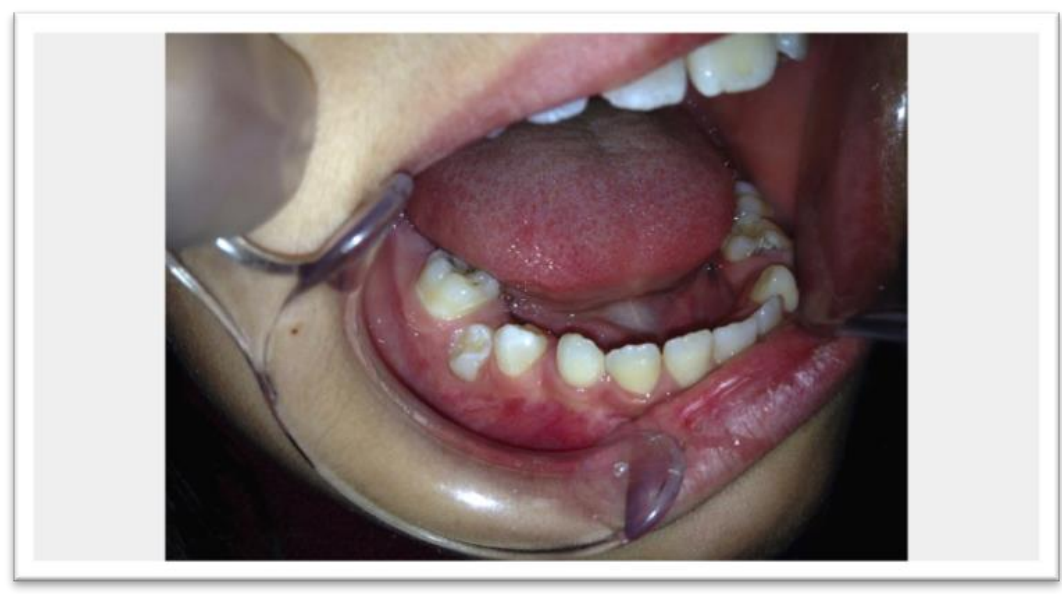

Figure 3: A clinical post-treatment image of the patient (month 14).

\section{DISCUSSION}

Mandibular cystic lesions show similar clinical and radiographic features, and histological evaluation is important in differential diagnosis $(7,8)$. Before biopsy, it is recommended to determine cyst boundaries by radiography and computed tomography (6). Panoramic mandibular radiography is sufficient in cysts seen in the mandible, whereas computed tomography provides more accurate information about the cysts in the maxilla (2). Obtaining three-dimensional data about the boundaries of the cyst is the additional advantage of using computed tomography for diagnostic purposes (2).

Previous studies have shown that the odontogenic cyst prevalence in Turkish population is $98.5 \%(7,9,10)$. In 
addition, the prevalence of odontogenic and nonodontogenic cysts has been reported to be $3.51 \%$ more in men compared to women, and cysts have been reported to be more common in the age of thirties $(24.2 \%)(7,11)$. The present case differs from the average as the patient was a 9-year-old female.

Patients with mandibular cysts usually have symptoms such as pain, swelling, and bad taste in the oral cavity (2). As in the present case, in some cysts, the patient has no clinical symptoms, and can only be diagnosed by examining panoramic radiographs taken for routine control (2). In such cases, the dentist's experience is important. These cases can be mixed up with tooth abscess and may end up with false tooth extraction (2). However, any delay in treatment leads to increased cyst size and delayed recovery (2).

The treatment of cysts in the literature shows similarities; however, the pre-diagnosis of the cyst, location, recurrence rate, size, the vicinity to the teeth and anatomical structures, and the age of the patient should be considered in the treatment $(2,3)$. The examinations have shown that marsupialization and decompression have been found to be more advantageous in the treatment of large cysts $(12,13)$. Marsupialization and decompression provide several advantages, such as gradual shrinkage of the cavity, prevention of tooth extraction, prevention of damage to adjacent anatomical structures, and reduction of the recurrence rate $(12,14)$. In our case, marsupialization was opted for because of the age of the patient and the presence of a compacted tooth, and it was aimed to let the tooth erupt into the oral cavity. Patient cooperation during treatment is important for keeping the cyst cavity clean and open $(12,15)$. In this case, the patient was highly cooperative. At the end of a 14-month follow-up, the radiography of the patient showed that although the cyst was not enucleated, radiolucency in the related region disappeared, and the tooth number 45 erupted into the oral cavity.
The extraction of the teeth located in the vicinity of the cyst may not be beneficial in every treatment and may also adversely affect the dental anatomy and some activities, such as chewing and speech (2). Considering these reasons, in the present case, it was aimed to let the tooth erupt into the oral cavity instead of extraction. The patient was referred to the orthodontic clinic following the eruption of the tooth 45 in the buccal direction.

As a result, a good preliminary evaluation, biopsy results, appropriate surgical treatment, and treatment planning according to the patient's age and recurrence rate of the cysts in the jaws yielded positive results (2). For large mandibular cysts, marsupialization is considered to be an appropriate and successful method in compatible patients.

\section{Researchers' Contribution Rate Statement: All} authors have read and approved the final version of the article.

Conflict of Interest: The authors declare that they have no conflict of interest.

Support and Acknowledgment: The authors deny any conflicts of interest related to this study.

Informed Volunteer / Consent Form: In this case, from the patient; the informed consent form was signed and approved.

\section{REFERENCES}

1. Sumbh B, Sumbh SG, Jain P, Pagare J. Classification of odontogenic cysts: a review. IOSR Journal of Dental and Medical Sciences. 2017;16(4):79-82.

2. Ağır H, Şen C, Işıl E, Ünal Ç, Üstündağ E, Keskin G. Çenenin odontojenik ve odontojenik olmayan kistleri: 25 olguda deneyimlerimiz. Kulak Burun Boğaz İhtis Derg. 2008;18(3):157-165.

3. Borah GL, Aziz SR. Tumors of the mandible. In: Mathes SJ, Hentz VR, eds. Plastic Surgery. 2th ed. Philadelphia. WB Saunders, 2006:91-157. 
4. Browne RM. The pathogenesis of odontogenic cysts: a review. J Oral Pathol. 1975;4(1):31-46.

5. Boyd JB, Assad CJ. The mandible. In: Achauer BM, Eriksson E, Coleman JJ, Kolk CV, Russell RC, Guyuron B, eds. Plastic Surgery: Indications, Operations, and Outcomes. 3rd ed. St. Louis. Mosby. 2000:1233-77.

6. Baştoklu S, Çelik M, Karabağlı P, Yıldırım G. Çene kistleri: Konya bölgesinde 274 olguda klinikopatolojik ve retrospektif bir çalışma. Genel Tip Derg. 2016;26(1):8-13.

7. Regezi JA, Sciubba JJ, Jordan RCK. Oral Pathology: Clinical Pathologic Correlations. 4th ed. St Louis. WB Saunders, 2003.

8. Rosai J. Rosai and Ackerman's Surgical Pathology. 10th ed. India. Elsevier, 2011.

9. Açikgöz A, Bulut EU, Özden B, Gündüz K. Prevalence and distribution of odontogenic and nonodontogenic cysts in a Turkish Population. Med Oral Patol Oral Cir Bucal. 2012;17(1):108-15.

10. Philipsen HP. Keratocystic odontogenic tumour. In: Barnes L, Eveson JW, Reichart P, Sidransky D, eds. World Health Organization Classification of Tumours. Pathology and Genetics of Head and Neck Tumors. Lyon. IARC Press, 2005:306-7.

11. Koparal M, Türker Alan H, Toprak Gündüz D, Gülsün B, Erdoğdu İH, İçen V ve ark. Geniş mandibuler kistlerin konservatif tedavisi: iki olgu sunumu. Turkiye Klinikleri J Dental Sci Cases. 2015;1(4):285-9.

12. Mejia JL, Donado JE, Basrani B. Active nonsurgical decompression of large periapical lesions-3 case reports. J Can Dent Assoc. 2004;70(10):691-4.

13. Anavi Y, Gal G, Miron H, Calderon S, Allon DM. Decompression of odontogenic cystic lesions: clinical long-term study of 73 cases. Oral Surg Oral Med Oral Pathol Oral Radiol Endod. 2011;112(2):164-9.
14. Bouquot JE. Odontogenic cysts and tumors. In: Neville BW, Damm DD, Allen CM, eds. Oral and Maxillofacial Pathology. 2th ed. Philadelphia. WB Saunders, 2002.

15. Jackson IT, Shaw K. Tumors of the craniofacial skeleton, including the jaws. In: McCarthy JG, eds. Plastic Surgery. $3^{\text {rd }}$ ed. Philadelphia. WB Saunders Company, 1990:336-411. 